\title{
A Study on Customer Perception Towards Supermarkets in Goa
}

\author{
Lamaan Sami, Pushpender Kumar
}

\begin{abstract}
People shift their buying from local retail stores to supermarkets, because of many reasons. This trend shift has not only been seen in metro cities but in small towns too. These change in perceptions of the customer insight the researcher and other stakeholder to study the reason behind it. This study tries to understand the demographic profile of the customers in Goa and compare the perception of customers towards supermarket and local retail stores. It has observed that people prefer supermarkets more as compared to the local retail store.
\end{abstract}

Keywords: Customer- Perception, Supermarket, Retail Store.

\section{INTRODUCTION}

Liberalization and globalization not only leads to the development and growth, but it also changes the standard culture of marketing and distribution of goods and services. It shifts the buying ways from local shops to malls and further moves to online shopping. Earlier people used to buy from the local retail shops (kirana shops), now they prefer to go and buy from supermarkets, which make the shopping supermarkets vary from various demographical factors.

\section{LITERATURE REVIEW}

There is adequate literature available on customer satisfaction or perceptions towards supermarkets, (Thuong ,2016) explore the satisfaction of customers towards supermarkets and for this he selected 4 supermarkets in Nguyen city and found that price is the one of the prominent factors which attracts the customers towards the supermarkets. (R. \& Gangatkar.J, 2015) Survey was conducted using a structured questionnaire of 100 respondents in Bangalore and found that customers have better perception of supermarkets as compared to provisional stores except price. Provision stores need to adopt more strategies to survive and grow in the long run. (Malhan, 2014)

Manuscript received on November 10, 2021.

Revised Manuscript received on November 25, 2021.

Manuscript published on November 30, 2021.

* Correspondence Author

Dr. Lamaan Sami, Assistant Professor, Department of Commerce, Aligarh Muslim University, Aligarh (Uttar Pradesh) India. E-mail: lamaansami@yahoo.com

Dr. Pushpender Kumar*, Assistant Professor, Institute of Management Studies (IMS) Ghaziabad (Uttar Pradesh) India. E-Mail: pushi.yadav@gmail.com

(C) The Authors. Published by Blue Eyes Intelligence Engineering and Sciences Publication (BEIESP). This is an open access article under the CC BY-NC-ND license (http://creativecommons.org/licenses/by-nc-nd/4.0/) and ways of living of the people. It brings the western experience different and easy. Perceptions towards

The author tried to measure the expectation level of the customers regarding the service quality in the food retail sector against their perception levels of the service quality in uchumi hypermarkets (a government owned enterprise) and to determine the gap between the customers' expectations and perception regarding service quality. The research concluded that the customers' expectation regarding service quality in uchumi supermarket is higher than their perceptions of service quality at uchumi. Customers expect high service quality at uchumi so if they don't meet the needs of the customers then it may result in dissatisfaction among the customers and losing customers to competitors. (Mohan, 2013) study the food retail supermarket stores in Bangalore city. He captured the 5 main factors i.e. Customer service, Brand variety, Store environment, Convenient location and Shopping convenience that impact customer satisfaction in food retail supermarkets, which can help food supermarket retailers formulate strategies and marketing activities to attract and retain customers. (Azad, Hossain, \& Parveen, 2012)Study the customer perception about supermarkets and also tried to estimate the factors which are responsible to satisfy the customers of supermarkets in Bangladesh. They conclude that there is no limit to the satisfaction level of the customers, as it differs from person to person. But there are some common factors which can determine the overall satisfaction of the customers of supermarkets. If the customers are satisfied by shopping in supermarkets then there is a positive attitude of customers towards supermarkets and will repeat their purchases. But if they are not satisfied, then the supermarket is not serving its purpose to the customers. (Abubakar, Mavondo, \& Clulow, 2011) investigate the customer ratings of importance of various attributes associated with supermarket shopping. The results suggested that nowadays the retail formats have become very sophisticated and standardized and the corporate reputation is ranked high. (Lu \& Lukoma, 2011) examined the overall dimensions and specific elements to measure the customer satisfaction level and also a comparative analysis was conducted between the three supermarkets. The study resulted in showing that the people like to buy from the most convenient supermarket therefore location is considered as the most important factor for retailers business. The critical factors of customer satisfaction of the supermarkets were location, staff, reliability, product quality and additional services.(Noyan $\boldsymbol{\&}$ Simsek, 2011)Customer satisfaction and loyalty are very important to develop the retail strategies. 


\section{A Study on Customer Perception Towards Supermarkets in Goa}

Store image and customer relationship proneness play an important role in creating satisfaction. Sample used in this study consists of customers shopping from 102 stores belonging to four Turkish supermarket chains in Istanbul. (Awng, 2008) compares the consumer's perception between superstores and family-run stores in Bangkok. Three super stores were selected to compare with family-run stores in the city.

\section{Objective of study}

1. To study the demographic profile of the customers who visit supermarkets and local retail stores.

2. To compare the customer perception towards supermarkets with local stores.

\section{METHODOLOGY}

The purpose of the study was to investigate customer's perception towards supermarkets in Goa. The study was carried out from December 2018 to March 2019. Using convenience sampling, a structured questionnaire was administered to 350 respondents. The total usable responses were 300 with a response rate of $86 \%$. The data was collected from students, businessmen, employed and unemployed people and also from housewives.

The data was collected using a structured questionnaire which was divided into two parts. The

First part tried to assess the respondent's demographic information, i.e. Gender, Age, Education, Marital Status, and Income, Occupation and Location. The second part related to various factors considered by customers while choosing the supermarket or local retail store for their shopping. Here, 10 statements were extracted from past research and respondents were asked to rank the extent to which they ranked highest rank (5) to lowest rank (1). In order to find out any significant difference in preference of customers, a paired sample t-test is used.

Table:1 Demographic Profile of Customers

\begin{tabular}{|c|c|c|c|c|c|}
\hline \multirow{2}{*}{$\begin{array}{c}\text { Demographic } \\
\text { Characteristics }\end{array}$} & \multirow{2}{*}{ Groups } & \multicolumn{2}{|c|}{ North Goa } & \multicolumn{2}{|c|}{ South Goa } \\
\hline & & $\#$ & $\%$ & $\#$ & $\%$ \\
\hline \multirow[b]{4}{*}{ Age } & Below 20 & 29 & 16.3 & 20 & 16.3 \\
\hline & $31-40$ & 44 & 24.7 & 31 & 25.0 \\
\hline & $41-50$ & 32 & 18.0 & 22 & 18.0 \\
\hline & $51-60$ & 11 & 6.2 & 7 & 6.0 \\
\hline \multirow{2}{*}{ Gender } & Male & 72 & 40.4 & 50 & 40.7 \\
\hline & Female & 106 & 59.6 & 72 & 59.3 \\
\hline \multirow{3}{*}{ Marital status } & Married & 95 & 53.3 & 65 & 53.3 \\
\hline & Unmarried & 82 & 46.0 & 56 & 46.0 \\
\hline & Divorced & 1 & 0.3 & 0 & 0.3 \\
\hline \multirow{3}{*}{ Education } & Professional & 25 & 14.0 & 17 & 14.0 \\
\hline & Graduation & 46 & 25.7 & 31 & 25.7 \\
\hline & Masters & 25 & 14.0 & 17 & 14.0 \\
\hline \multirow{4}{*}{ Annual Income } & Less than 1 lakh & 39 & 21.7 & 26 & 21.7 \\
\hline & 2-5 lakhs & 84 & 47.3 & 58 & 47.3 \\
\hline & 5-8 lakhs & 49 & 27.3 & 33 & 27.3 \\
\hline & Above 8 lakhs & 7 & 3.7 & 4 & 3.7 \\
\hline \multirow{2}{*}{ Nature of family } & Nuclear family & 96 & 54.0 & 66 & 54.0 \\
\hline & Joint family & 82 & 46.0 & 56 & 46.0 \\
\hline
\end{tabular}

Source: Author's Compilation

The above table explains that the demographic profile of the respondents with percent. It is observed that respondents from the age group of 18-30 prefer visiting supermarkets i.e. (32\%), it means supermarkets attract the youth. In terms of gender 178 female respondents prefer buying from supermarket as compared to male respondents which consist of 122 male respondents. In terms of marital status - married (53\%) people mostly prefer shopping in supermarkets as compared to unmarried people which consist of 138 respondents.

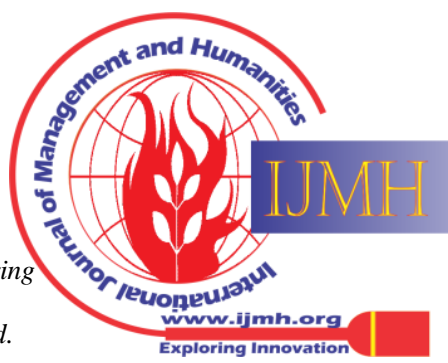


In terms of education, Graduate people (25\%) respondents prefer shopping in supermarkets than that of other groups in the education category. In terms of income, 2 lakh to 5 lakh of the income group prefer buying products from supermarkets. In terms of occupation, (30\%) students prefer shopping from the supermarket. In terms of the nature of the family, 162 respondents from nuclear families prefer shopping in supermarkets. In terms of location, 178 respondents from North Goa prefer shopping in supermarkets. The Remaining 122 respondents prefer shopping in supermarkets.

Table: 2 Factor which attract to visit

\begin{tabular}{|l|c|c|c|c|}
\hline \multirow{2}{*}{ Factor } & \multicolumn{2}{|c|}{ Super Market } & \multicolumn{2}{|c|}{$\begin{array}{c}\text { Local } \\
\text { Retail } \\
\text { Store }\end{array}$} \\
\cline { 2 - 6 } & $\#$ & $\%$ & $\#$ & $\%$ \\
\hline Better customer service & 35 & 12.7 & 2 & 8.1 \\
\hline location of the store & 33 & 12.0 & 9 & 32.4 \\
\hline Comfortable shopping environment & 132 & 48.5 & 5 & 16.2 \\
\hline Availability of credit & 27 & 9.8 & 8 & 29.7 \\
\hline Product price is reasonable & 46 & 16.9 & 4 & 13.5 \\
\hline Total Respondent & 272 & & 28 & \\
\hline
\end{tabular}

Source: Author's Compilation

From the above table, it is observed that $90.3 \%$ of total respondents prefer the supermarket and only $9.7 \%$ respondents prefer local retail stores. $48.5 \%$ of the respondents prefer to shop in supermarkets because of the availability of all products at one place as customers want everything at ease. Out of 272 respondents 16.9 prefer shopping in supermarkets due to product price being reasonable. Rest of the respondents said they prefer supermarkets because of better customer service, location of the supermarket and availability of credit.32.4\% respondents prefer local stores because of the location of the store, they find buying is easier and convenient from the nearby local store. $29.7 \%$ respondents visit due to availability of credit facilities; they prefer buying from local stores. Rest of the respondents said they prefer local stores because of the comfortable shopping environment, Product prices are reasonable and better customer service. It can be concluded that, location of the store and availability of credit at a local retail store attracts the customer, whereas availability of the entire product at one place and reasonable price at supermarket attracts the customer. In order to compare the customer perception towards supermarkets with local stores, the hypothesis has been framed and tested by the use of paired- sample t-test. Ho: There is no significant difference exist between the perception of consumers using supermarket and local store

Table: 3 Paired Samples Statistics

\begin{tabular}{|cc|c|c|c|c|}
\hline & & Mean & $\mathbf{N}$ & $\begin{array}{c}\text { Std. } \\
\text { Deviation }\end{array}$ & $\begin{array}{c}\text { Std. Error } \\
\text { Mean }\end{array}$ \\
\hline $\begin{array}{c}\text { Pair } \\
1\end{array}$ & $\begin{array}{c}\text { Supermarke } \\
\mathrm{t}\end{array}$ & 3.5987 & 300 & .69983 & .04040 \\
& Local store & 2.9210 & 300 & .69344 & .04004 \\
\hline
\end{tabular}

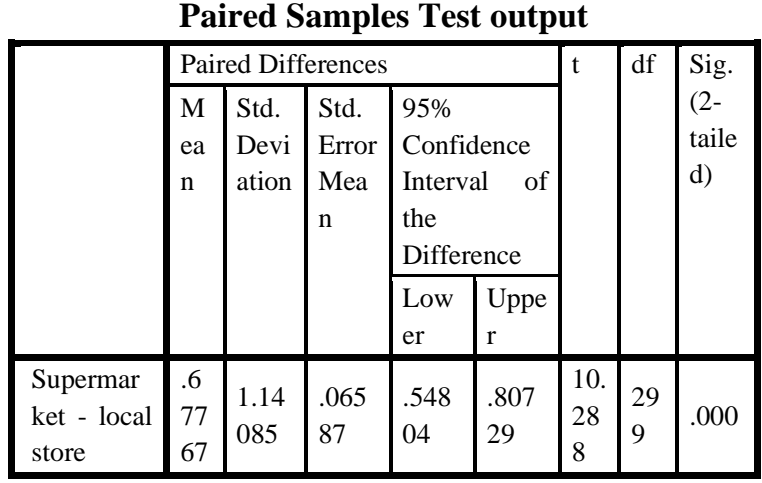

In paired sample t- test the mean values of both supermarket and local store are compared the result showed that the t-value is significant $(0.000<0.05)$ at the confidence level of $95 \%$. Therefore, the null hypothesis is rejected and an alternate hypothesis is accepted, which indicates that there is a significant difference in the consumer perception of local retail stores and supermarkets. It also observes that the mean score of supermarkets is higher which indicates that the experience at supermarkets is more as compared to local stores. Factors such as special discount on occasions, time saving, mode of payment, good quality products etc. leads to prefer-ability of supermarkets over local retail stores.

\section{CONCLUSION}

Customer perceptions is psychological phenomena which vary from individual to individual, this perception also vary due to certain demographical factor. In the present study it is observe that youth are get attracted towards the supermarket, people having income range to 2-5 lakh visiting more at supermarket. It also observes that there is no difference in demographic profile of the customer in terms of location. People in Goa prefer to visit supermarkets as compared to the local retail store because various factors such as special discount on occasions, time saving, mode of payment, good quality products etc. leads to prefer-ability of supermarkets over local retail stores.

\section{REFERENCES}

1. Abubakar, B., Mavondo, F., \& Clulow, V. (2011). Customer satisfaction with supermarket retail shopping.

2. Di, A. (2008). Consumers perception toward retail stores; comparing between superstores and family-run stores in Bangkok.

3. Hariharan, D. S., \& Selvakumar, D. N. (2014). A study on consumer satisfaction towards supermarkets. Indian journal of research, volume 3 Issue:12.

4. Lu, P. H., \& Lukoma, I. G. (2011). Customer satisfaction towards retailers.

5. Malhan, P. (2014). A Empirical study of customers expectations and perceptions of service quality;A case study of uchumi megastores in kenya. Internantional journal of management and International business studies, Volume 4,Number 3.

6. Malik, S., \& Zameer, A. (2016). Determinants of consumer satisfaction at supermarkets; An empirical study from Pakistan. Pg.625-631.

7. Marx, N. M., \& Erasmu, A. C. (2006). Customer satisfaction with customer service and service quality in supermarkets in a third world context. Association for consumer research, 77-85. 


\section{A Study on Customer Perception Towards Supermarkets in Goa}

8. Mohan, R. (2013). To identify factors impacting customer satisfaction in food retail supermarkets. Institute of management,christ university.

9. Noyan, F., \& Simsek, G. G. (2011). Structural determinants of customer satisfaction in loyalty models: Turkish retail supermarkets. Elevier ltd.

10. Paul, J., Sankarnarayanan, K. G., \& Mekoth, N. (2016). Consumer satisfaction in retail stores: Theory and implications. International journal of consumer studies.

11. Ping, W. S. (2012). The relationship between customer satisfaction with customer services and store image towards supermarkets; A case study in Sibu.

12. R., S., \& Gangatkar.J, A. (2015). A study on comparative analysis of consumer perception towards supermarkets and provision stores in Banglore. International journal of engineering and management sciences, volume 6(3), 149-154.

13. Thương, N. T. (2016). Factors inluencing customer satisfaction towards supermarkets in Thai Nguyen city, Vietnam. International journal of economics,commerce and management, 1-474.

\section{AUTHOR PROFILE}

Dr. Lamaan Sami, Ph.D working as Assistant Professor at Aligarh Muslim University, where she delivers courses on Business environment and Marketing. Her current research includes project in domain of Consumer Behavior. Her research works published in various reputed journals and she presented her research at various national and international conferences.

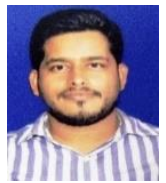

Pushpender Kumar, is Assistant Professor at IMS Ghazaibad, where he delivers courses on Banking and Finance. His current research includes projects in domain of Mergers and Acquisition, banking, international trade and Finance. 